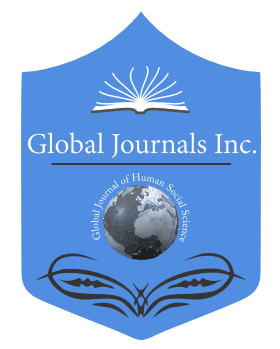

\title{
Body, Learning Facilitator
}

\author{
By Manuela Valentini
}

University of Urbino Carlo Bo

Abstract- The school is a safe zone where the curriculum is determined, in a shared manner; where the actors (pupils and teachers), each in their own roles, aim at a project of professional and human, personal and collective growth. A system involving theory, practice and technique combined with relationships and emotions: head and heart together. An encounter between verbal and non-verbal languages, between scientific and humanistic areas where thought becomes actions and actions become thinking, in a thoughtful action. The aim of this intervention is to promote the culture of interdisciplinarity, to offer a focus on the importance of the Integrated Curriculum, also in the university sphere as it is increasingly urgent to create a network of synergies to foster a unity of knowledge that offers a holistic-global vision also by proposing joint scientific work for a biodiversity of languages that means protecting a plurality of information useful for knowledge and thus for the protection of all. Education is developed on transversal competences, soft skills training, inclinations identified in each one (pupil, teacher), which impact on disciplinary knowledge; as well as defining hard skills; to reflect on a methodological framework where the body becomes the protagonist, the glue, the bridge of meanings, transforming them and transporting them into other languages.

Keywords: soft skills training, hard skills, analogue language, holistic view of knowledge.

GJHSS-A Classification: FOR Code: 130205p

Strictly as per the compliance and regulations of:

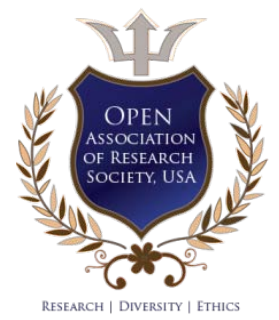

(C) 2021. Manuela Valentini. This is a research/review paper, distributed under the terms of the Creative Commons AttributionNoncommercial 3.0 Unported License http://creativecommons.org/licenses/by-nc/3.0/), permitting all non-commercial use, distribution, and reproduction in any medium, provided the original work is properly cited. 


\title{
Body, Learning Facilitator
}

\author{
Manuela Valentini
}

Abstract The school is a safe zone where the curriculum is determined, in a shared manner; where the actors (pupils and teachers), each in their own roles, aim at a project of professional and human, personal and collective growth. A system involving theory, practice and technique combined with relationships and emotions: head and heart together. An encounter between verbal and non-verbal languages, between scientific and humanistic areas where thought becomes actions and actions become thinking, in a thoughtful action. The aim of this intervention is to promote the culture of interdisciplinarity, to offer a focus on the importance of the Integrated Curriculum, also in the university sphere as it is increasingly urgent to create a network of synergies to foster a unity of knowledge that offers a holistic-global vision also by proposing joint scientific work for a biodiversity of languages that means protecting a plurality of information useful for knowledge and thus for the protection of all. Education is developed on transversal competences, soft skills training, inclinations identified in each one (pupil, teacher), which impact on disciplinary knowledge; as well as defining hard skills; to reflect on a methodological framework where the body becomes the protagonist, the glue, the bridge of meanings, transforming them and transporting them into other languages. This is not a palliative but a recognition of its formative, educational, cognitive, social and relational value, in order to strive for an alliance between knowledge. After a theoretical-bibliographical excursus, some examples of articles/protocols selected by the main search engines, from 2003 to 2020, for pupils aged 5 to 18 and for teachers were taken into consideration. A bibliographical research in Italy and abroad on state of the art, developments, novelties, of the school curriculum to see if they are increasingly suitable for the person-pupil, with the body in motion as a protagonist. Learning passes through the body understood in a holistic sense, an inhabited place by the multitude where theory becomes a practiced, technique, and is transformed into experiences of bodies in movement that interact with others different from themselves, coming to share numbers, formulas, telling stories, history, places near and far, customs, traditions; knowledge inhabited in bodies, in the body that will have the opportunity to inhabit space and time. The results have shown that the implementation of an integrated curriculum, with its natural interdisciplinary vocation, does not diminish the epistemological autonomy of the disciplines, but rather amplifies their meanings and significance, redefining boundaries and paths and placing them among the threads of complexity. In conclusion, we can claim that knowledge experienced in a circular way will enable us to know and do better, and if this knowledge has been learned well, it will have an added value: a connection that is also necessary to define new professions.

Keywords: soft skills training, hard skills, analogue language, holistic view of knowledge.

Author: Department of Humanities - University of Urbino Carlo Bo, Italy. e-mail:manuela.valentini@uniurb.it

\section{INTRODUCTION}

1 eading the 17 Sustainable Development Goals to be achieved by 2030 (ONU, 2015) as well as making us think in general, by forma mentis, in particular, leads us to analyze the: 3 Ensuring healthy lives and promoting well-being for all at all ages, 4 Ensuring inclusive and equitable quality education and promoting lifelong learning opportunities for all and 16 Promoting peaceful and inclusive societies geared towards sustainable development, ensuring access to justice for all and building effective, accountable and inclusive institutions at all levels. Goal 3 inevitably focuses on health as a precious asset for all human beings of all ages, in order to ensure full wellbeing. A well-being that involves first of all coming to terms with oneself and then looking at the world of others, of things, of the environment. An awareness that begins immediately, the moment we come into the world, having to learn who we are, how we are made (physically, cognitively, in relations, socially) within our potential and limits.

A study, a learning that at the beginning is not learned by reading a book but by intuition, exploring, understanding, deciphering, interpreting, enhancing our own body; a discovery that begins gradually by perceiving it and then knowing it in its globality, segmentarity and intersegmentarity states and finally becoming aware of it. The structuring and consolidation of the body scheme is a long process that lasts about twelve years from birth, demonstrating that not only the quality of the stimuli received in this very important period of developmental age will make a difference in the human growth of the child, but also the quantity of experiences and knowledge learned will give added value to the path of education and training. Attention to health for total, overall wellbeing, which in addition to preventing illnesses must be concerned with the mental, psychic-physical balance which will make the body feel entirely good, as a whole. Objective 4 has as its protagonist education and learning guaranteed to each and everyone, in an inclusive and equitable way, understood in a new way, re-discovering, re-inventing, re-formulating, re-structuring new forms of teaching, aiming at an integrated curriculum in all school levels including the University: new methodological, didactic, educational approaches that can better adapt to the new generations, that live in a world in a state of very strong transformation, where not adapting would be equivalent to forced isolation, segregation contrary to inclusion; goal 16 summarizes the concept of inclusive 
institutions in the perspective of sustainability that "implies a constant and preferably increasing well-being (environmental, social, economic) and the perspective of leaving to future generations a quality of life not inferior to the current one. This approach can be formalized through social welfare functions, i.e. relations between the well-being of society and the variables that contribute to the economic status and quality of life" (Encyclopedia online Treccani, 2021). Three goals that find their synthesis in three keywords: health; education; institution giving the set of what has always been necessary for man, but in an optimized way, revisited and corrected because it is understood that there is a need for adjustments, a revision, a positive mutation, an evolution, from the state of the art.

\section{IDENTITY AND BODY}

And it is precisely from art that we want to begin, a high, immense art such as that of Leonardo, who put his Vitruvian Man, around 1492, preserved and protected in the Gallerie dell'Accademia in Venice, at the centre of the universe, man as the identity of the world. Everything starts from here, the beginning of a path that will lead him to sign, autograph with his own body, the Being Person, yes the set of bones, muscles, apparatuses that are united in thought, soul and action in harmony, will go to relate to the world protecting and safeguarding the natural Mind balance. An education of the body that begins at birth, in the age of development and that must through necessity continue throughout our lives. A body image that, must be helped to form in the family, at school, during leisure time in a measured way, attentive to the specific individuality to remove, clear the field from seeing reflected in the mirror transformed figures, in excess of too much physicality, muscularity or, on the contrary, tissue paper bodies, which in both cases are not recognized in health, in the same way when with exaggerations of cosmetic surgery, you want to give your self another image of itself. Making peace with our bodily scheme means taking care of it from a very young age with healthy movement, motor activity that makes us meet, understand, discover, and become familiar with everything that surrounds us. The child can find itself, if immediately stimulated and intimately projected to know itself through motivating content, fun, appropriate, propaedeutic, various, playful in movement, the meaning and potential related to itself internalizing a fundamental component: the benefit of a body that moves. Not only seen under the profile of purely anatomical, physiological, physical exercise but going further, considering it in its entirety: a body that acts, thinks, loves and is loved, located in an adequate sustainable environment. A positive environment in the family, at school, at work, in friendships, in experiencing the good in each of us and the beauty that surrounds us. "Let us regularly feed on good things, beautiful acts, and the ugly will have nothing interesting. Let us be in the company of wise people, humble people, people who know how to love. To remain in beauty" (Rosini, 2018, p. 304). A beauty that goes through recognizing oneself, accepting oneself, moving on, structuring stage by stage the image of oneself: from the bodily experiences, perceived and represented living first of all with those sensory education experiences, exercising the basic motor schemes, motor skills, lateralization arriving at the game-sport and with knowledge and practice of sports. An excellent exercise that also allows access to autonomy, self-care, stimulating attention and working memory. "The working memory is a responsible system for the maintenance and temporary processing of information while performing various kinds cognitive tasks. It allows, in other words, the memory of the elements with which one comes into contact to remain alive, so that it can then be used for the purpose of a goal" (Cottini, 2019, p. 28). Memories that will contribute to the formation of the little, future man and citizen and then if they are experienced in motion, in a playful, motivating way going towards knowledge obviously, will remain indelible and useful for higher learning. The body with its language, with its grammar, helps to determine our figure, our person, specifying the identity, defining a unique style, inalienable, unrepeatable. "You cannot access the world except through that space that the body unfolds around itself in the form of proximity or distance from things" (Galimberti, 2002, p. 73). A space to be occupied in a time to be used for your own human, cultural, life growth.

\section{Integrated Curriculum Research IN MOTION}

The body is our first cognitive instrument; the look towards ourselves, the look towards others direct the construction of our forma mentis, in an objectified and objectivising space that is constructed in the very act of being social. Our bodies inhabited by practice cross cultural contexts and systems, become a preferential channel for an integrated learning characterized by the multidimensionality of the sensemotor approach.

There are many studies, including very recent ones, which define the motor education within an integrated curriculum characterized by openness and flexibility, meeting and interweaving of blurred boundaries in which to integrate knowledge and skills to avoid rigid mental closures that characterize the old disciplinary body.

In particular, among the various examined articles, a number of protocols from 2003 to 2020 were taken into consideration, reporting study cases, bibliographic analyses, longitudinal studies, aimed at verifying the effects of an integrated curriculum. 
The social actors subject of the research vary from Primary-Secondary School pupils to teachers, we have also spaced within the international dimension, European and Italian specifically, to show the different results brought to light by the investigations carried out by the researchers.

Thorburn \& Collins (2003) carried out 40 semistructured interviews, conducted in small groups and targeting both teachers and Secondary School pupils in Scotland. The study revealed a significant disparity in the pedagogical practices that teachers adopt. With the aim of investigating the interaction between teaching, learning and assessment in an Integrated Curriculum context, planning, methodology and implementation were considered and how the pedagogical factors linked to the students' achievement have been identified.

Hastie (2013) in "The Biome Project: developing a legitimate parallel curriculum for Physical Education and Life Sciences" describes the results related to a parallel curriculum project between life sciences and motor education. The subjects taken into consideration are pupils of the second and the fifth classes of Primary School, divided into teams, each of which represented different animal species and biomes, that participated in motor competitions. The results highlighted how the organization of this project has favored the achievement of better ratings in both subjects involved, thanks to the conjunction of both curricular and micro-political elements, wisely integrated, motivating students and allowing the strengthening of contents.

Filippou (2015) in Greece, carried out a survey involving 262 students (136 males and 126 females) at Secondary School. The aim was to analyse the effects of an interdisciplinary traditional dance programme, linked to related historical-anthropological processes, on pupils' performance.

The experimental group participated in the innovative program for 8 weeks, while the control group followed the classical teaching.

In order to assess the learnings, an Orientation Questionnaire was carried out which showed that the interdisciplinary program reduced the rates of Ego reinforcement and protection, while increasing the social and personal goal of the students, especially males.

Seeds, Pollom \& Burtun (2015) in their study involved pupils between the ages of 5 and 6 . A Physical Education teacher worked with Kindergarten teachers, a Science teacher and the Science curriculum coordinator in an attempt to integrate Science with motor activity. The results showed how connecting multiple disciplines through a common experience fuels engagement in children and helps them to better remember what they learn.

Coral-Mateu \& Lleixà Arribas (2016) carried out a Research-Action involving Primary School pupils (26 pupils aged 10-11) with the aim of identifying specific strategies for teaching Physical Education in the content and in the Foreign Language integrated learning, therefore the practice of Motor Education had been declined through the use of CLIL. This study demonstrates how a CLIL-based PE programme can be used not only to improve language and thus learning, but also to systematise teaching effectively.

In Italy, Nicolosi, Greco \& Di Stefano (2017) activated workshops and interdisciplinary design processes involving Primary School teachers in order to verify the results of the application of a collaborative model in the planning of didactic units integrating Physical Education in the school curriculum. What emerged is the difficulty of building a positive and constructive dialogue among colleagues: "the general perception of teachers on the design, which was described during the focus groups having difficulty with constructive dialogue with colleagues, had a relapse in the extended confrontation phases of the interdisciplinary co-design process" (Nicolosi, Greco \& Di Stefano, 2017, p.99). Therefore, the integrated curriculum is not a mere application of conventional practices and rules, but a shared elaboration that goes beyond didactics, involving also issues related to one's role as a teacher, how one understands one's profession, the idea of knowledge and the idea of each one's personal school.

Cecchini \& Carriedo (2020), in Spain, carried out an experimental research on a sample of pupils aged $6-7$ in order to verify the effects of an interdisciplinary educational approach integrating Physical Education and Mathematics on light and moderately vigorous physical activity, sedentary behaviour and subtraction learning. The experimental group was subjected to the interdisciplinary approach, the control group continued with traditional teaching. As for the results obtained, there was an improvement in terms of mathematical skills in both groups, but only the experimental group considerably reduced sedentary behaviour by increasing the levels of motor activity: light, moderate, vigorous. 
Table 1

\begin{tabular}{|c|c|c|c|c|c|c|}
\hline Authors & Title & $\begin{array}{c}\text { Country } \\
\text { and Setting }\end{array}$ & Activities & Target & Results & $\begin{array}{l}\text { Publication and } \\
\text { Search Engine }\end{array}$ \\
\hline $\begin{array}{c}\text { Malcolm } \\
\text { Thorburn } \\
\text { Dave } \\
\text { Collins }\end{array}$ & $\begin{array}{l}\text { "Integrated } \\
\text { curriculum } \\
\text { models and } \\
\text { their effects on } \\
\text { teachers' } \\
\text { pedagogy } \\
\text { practices" }\end{array}$ & $\begin{array}{l}\text { Scotland } \\
\text { (UK); semi- } \\
\text { structured } \\
\text { small group } \\
\text { interviews. }\end{array}$ & $\begin{array}{l}\text { Studies about } \\
\text { the } \\
\text { interrelationship } \\
\text { between } \\
\text { teaching, } \\
\text { learning and } \\
\text { assessment in } \\
\text { an Integrated } \\
\text { Curriculum } \\
\text { context. }\end{array}$ & $\begin{array}{l}\text { Students } \\
\text { aged } 11-18 \\
\text { and } \\
\text { teachers }\end{array}$ & $\begin{array}{l}\text { The findings } \\
\text { address the } \\
\text { identified } \\
\text { pedagogical } \\
\text { factors for } \\
\text { commentary on } \\
\text { teaching- } \\
\text { learning quality } \\
\text { and how these } \\
\text { factors link to } \\
\text { students } \\
\text { achievement. }\end{array}$ & $\begin{array}{c}\text { European } \\
\text { Physical } \\
\text { Education } \\
\text { Review, Vol 9, } \\
\text { Issue 2, pp. 185- } \\
209 \text { - } 2003 \\
\text { Search engine: } \\
\text { EBSCO (UrbIS - } \\
\text { Urbino Integrated } \\
\text { Search) }\end{array}$ \\
\hline $\begin{array}{c}\text { Peter } \\
\text { Andrew } \\
\text { Hastie }\end{array}$ & $\begin{array}{l}\text { "The Biome } \\
\text { Project: } \\
\text { developing a } \\
\text { legitimate } \\
\text { parallel } \\
\text { curriculum for } \\
\text { Physical } \\
\text { Education and } \\
\text { Life Sciences" }\end{array}$ & $\begin{array}{l}\text { Alabama } \\
\text { (USA); } \\
\text { experimental } \\
\text { research in } \\
\text { the } \\
\text { classroom } \\
\text { and } \\
\text { gymnasium. }\end{array}$ & $\begin{array}{l}\text { Describe the } \\
\text { results of a C.I. } \\
\text { between Life } \\
\text { Sciences and } \\
\text { Physical } \\
\text { Education. }\end{array}$ & \begin{tabular}{c}
\multicolumn{2}{c}{ Students } \\
aged 7 - \\
11
\end{tabular} & $\begin{array}{l}\text { The design of } \\
\text { the project } \\
\text { allowed for } \\
\text { extensive } \\
\text { content } \\
\text { coverage, and } \\
\text { the components } \\
\text { of fun, curiosity, } \\
\text { and participation } \\
\text { were prominent } \\
\text { from start to } \\
\text { finish. }\end{array}$ & $\begin{array}{c}\text { Journal of } \\
\text { Education 3-13; } \\
\text { International } \\
\text { Journal of } \\
\text { Primary, } \\
\text { Elementary and } \\
\text { Early Years } \\
\text { Education, Vol } \\
41, \text { Issue 5, pp. } \\
462-476-2013 \\
\text { Search engine: } \\
\text { Research Gate } \\
\end{array}$ \\
\hline $\begin{array}{l}\text { Filippos } \\
\text { Filippou }\end{array}$ & $\begin{array}{c}\text { "The effect of } \\
\text { an } \\
\text { interdisciplinary } \\
\text { Greek } \\
\text { traditional } \\
\text { dance, history, } \\
\text { and } \\
\text { anthropology } \\
\text { program on } \\
\text { male and } \\
\text { female } \\
\text { students' } \\
\text { achievement } \\
\text { goal } \\
\text { orientations" } \\
\end{array}$ & $\begin{array}{l}\text { Greece; } \\
\text { sixteen } \\
\text { cross- } \\
\text { curricular } \\
\text { meetings } \\
\text { that took } \\
\text { place during } \\
\text { Physical } \\
\text { Education } \\
\text { hours. }\end{array}$ & $\begin{array}{l}\text { Investigating the } \\
\text { effects of an } \\
\text { interdisciplinary } \\
\text { program on } \\
\text { traditional Greek } \\
\text { dances with } \\
\text { supplements } \\
\text { from history and } \\
\text { anthropology for } \\
\text { the achievement } \\
\text { of a "goal- } \\
\text { oriented" } \\
\text { mindset. }\end{array}$ & $\begin{array}{l}\text { Students } \\
\text { aged } 12-13\end{array}$ & $\begin{array}{c}\text { There was a } \\
\text { significant } \\
\text { reduction in Ego } \\
\text { reinforcement } \\
\text { and protection, } \\
\text { a major increase } \\
\text { in personal } \\
\text { development } \\
\text { and social } \\
\text { purpose. }\end{array}$ & $\begin{array}{c}\text { Journal of } \\
\text { Physical } \\
\text { Education and } \\
\text { Sport (JPES), Vol } \\
\text { 15, Issue 3, Art } \\
\text { 92, pp. 610-614- } \\
\text { 2015 Search } \\
\text { engine: Research } \\
\text { Gate }\end{array}$ \\
\hline $\begin{array}{l}\text { April } \\
\text { Seeds } \\
\text { Gretchen } \\
\text { Pollom } \\
\text { Bill } \\
\text { Burton }\end{array}$ & $\begin{array}{l}\text { "Physical } \\
\text { Education } \\
\text { meets Physical } \\
\text { Science: An } \\
\text { interdisciplinary } \\
\text { lesson allows } \\
\text { students to } \\
\text { experience } \\
\text { Physical } \\
\text { Science } \\
\text { firsthand" }\end{array}$ & $\begin{array}{l}\text { Texas } \\
\text { (USA); } \\
\text { lectures and } \\
\text { activities in } \\
\text { the gym. }\end{array}$ & $\begin{array}{c}\text { A Physical } \\
\text { Education } \\
\text { teacher worked } \\
\text { with } \\
\text { Kindergarten } \\
\text { teachers, a } \\
\text { Science teacher, } \\
\text { and the Science } \\
\text { curriculum } \\
\text { coordinator in an } \\
\text { effort to integrate } \\
\text { science with } \\
\text { motor activity. }\end{array}$ & $\begin{array}{l}\text { Students } \\
\text { aged 5-6 }\end{array}$ & $\begin{array}{c}\text { Connecting } \\
\text { multiple } \\
\text { disciplines } \\
\text { through a } \\
\text { common } \\
\text { experience fuels } \\
\text { engagement in } \\
\text { children and } \\
\text { helps them } \\
\text { better remember } \\
\text { what they learn. }\end{array}$ & $\begin{array}{c}\text { National Science } \\
\text { Teachers } \\
\text { Associatio, } \\
\text { Science and } \\
\text { Children, Vol 52, } \\
\text { Issue 6, pp. 39-44 } \\
\text { - 2015 } \\
\text { Search engine: } \\
\text { EBSCO (UrbIS - } \\
\text { Urbino Integrated } \\
\text { Search) }\end{array}$ \\
\hline $\begin{array}{l}\text { Josep } \\
\text { Coral- } \\
\text { Mateu } \\
\text { Teresa } \\
\text { Lleixà } \\
\text { Arribas }\end{array}$ & $\begin{array}{l}\text { "Physical } \\
\text { Education in } \\
\text { content and } \\
\text { integrated } \\
\text { language } \\
\text { learning: } \\
\text { successful }\end{array}$ & $\begin{array}{l}\text { Barcelona } \\
\text { (Spain); } \\
\text { action } \\
\text { research. }\end{array}$ & $\begin{array}{l}\text { To identify PE in } \\
\text { content and } \\
\text { integrated } \\
\text { language } \\
\text { learning (PE-in- } \\
\text { CLIL) teaching } \\
\text { strategies that }\end{array}$ & $\begin{array}{c}\text { Students } \\
\text { aged } 10-11\end{array}$ & $\begin{array}{c}\text { Significant } \\
\text { improvements at } \\
\text { the oral level } \\
\text { using the PE-in- } \\
\text { CLIL approach. } \\
\text { It is also shown } \\
\text { how a PE-in- }\end{array}$ & $\begin{array}{c}\text { International } \\
\text { Journal of } \\
\text { Bilingual } \\
\text { Education and } \\
\text { Bilingualism, Vol } \\
\text { 19, Issue 1, pp. } \\
\text { 108-126-2016 }\end{array}$ \\
\hline
\end{tabular}




\begin{tabular}{|c|c|c|c|c|c|c|}
\hline & $\begin{array}{c}\text { interaction } \\
\text { between } \\
\text { Physical } \\
\text { Education and } \\
\text { English as a } \\
\text { foreign } \\
\text { language" }\end{array}$ & & $\begin{array}{l}\text { improve oral } \\
\text { communication } \\
\text { and to verify that } \\
\text { significant } \\
\text { improvements } \\
\text { occur in both } \\
\text { listening } \\
\text { comprehension } \\
\text { and interaction. }\end{array}$ & & $\begin{array}{c}\text { CLIL } \\
\text { programme also } \\
\text { improves the } \\
\text { teaching itself. }\end{array}$ & $\begin{array}{l}\text { Search engine: } \\
\text { EBSCO (UrbIS - } \\
\text { Urbino Integrated } \\
\text { Search) }\end{array}$ \\
\hline $\begin{array}{c}\text { Simona } \\
\text { Nicolosi } \\
\text { Carla } \\
\text { Greco } \\
\text { Salvatore } \\
\text { Di } \\
\text { Stefano }\end{array}$ & $\begin{array}{l}\text { "Integrating } \\
\text { Physical } \\
\text { Education into } \\
\text { the Primary } \\
\text { School } \\
\text { Curriculum. A } \\
\text { collaborative } \\
\text { approach to } \\
\text { interdisciplinary } \\
\text { teaching." }\end{array}$ & $\begin{array}{l}\text { Italy; focus } \\
\text { groups and } \\
\text { workshops. }\end{array}$ & $\begin{array}{l}\text { To analyse the } \\
\text { results of the } \\
\text { application of a } \\
\text { collaborative } \\
\text { model in the } \\
\text { planning of } \\
\text { teaching units } \\
\text { that integrate } \\
\text { Physical } \\
\text { Education into } \\
\text { the Primary } \\
\text { School } \\
\text { curriculum. }\end{array}$ & Teachers & $\begin{array}{l}\text { The choice of a } \\
\text { C.I. approach } \\
\text { involves both } \\
\text { technical } \\
\text { aspects of } \\
\text { teaching design } \\
\text { and } \\
\text { implementation } \\
\text { and the very way } \\
\text { in which } \\
\text { teachers } \\
\text { interpret } \\
\text { knowledge. }\end{array}$ & $\begin{array}{c}\text { Training \& } \\
\text { Teaching XV - } 2 \text { - } \\
2017 \\
\text { ISSN 1973-4778 } \\
\text { print - 2279-7505 } \\
\text { on line doi: } \\
\text { 107346/-fei-XV- } \\
\text { 02-17_09 C) } \\
\text { Pensa MultiMedia } \\
\text { Search engine: } \\
\text { EBSCO (UrbIS - } \\
\text { Urbino Integrated } \\
\text { Search) }\end{array}$ \\
\hline $\begin{array}{c}\text { Jose A. } \\
\text { Cecchini } \\
\text { Alejandro } \\
\text { Carriedo }\end{array}$ & $\begin{array}{l}\text { "Effects of an } \\
\text { Interdisciplinary } \\
\text { Approach } \\
\text { Integrating } \\
\text { Mathematics } \\
\text { and Physical } \\
\text { Education on } \\
\text { Mathematical } \\
\text { Learning and } \\
\text { Physical } \\
\text { Activity Levels" }\end{array}$ & $\begin{array}{l}\text { Spain; } \\
\text { experimental } \\
\text { research. }\end{array}$ & $\begin{array}{l}\text { To examine the } \\
\text { effects of an } \\
\text { interdisciplinary } \\
\text { educational } \\
\text { approach } \\
\text { integrating } \\
\text { Physical } \\
\text { Education and } \\
\text { Mathematics on } \\
\text { light and } \\
\text { moderately } \\
\text { vigorous physical } \\
\text { activity (PA), } \\
\text { sedentary } \\
\text { behavior, and } \\
\text { subtraction } \\
\text { learning. }\end{array}$ & $\begin{array}{l}\text { Students } \\
\text { aged 6-7 }\end{array}$ & $\begin{array}{l}\text { The two } \\
\text { intervention } \\
\text { programs } \\
\text { (interdisciplinary } \\
\text { and traditional) } \\
\text { were both } \\
\text { successful in } \\
\text { improving } \\
\text { students' Math } \\
\text { skills; however, } \\
\text { only students in } \\
\text { the group with } \\
\text { interdisciplinary } \\
\text { intervention } \\
\text { reduced their } \\
\text { sedentary } \\
\text { behavior and } \\
\text { increased their } \\
\text { light and } \\
\text { moderately } \\
\text { vigorous PA } \\
\text { levels. }\end{array}$ & $\begin{array}{c}\text { Journal of } \\
\text { Teaching in } \\
\text { Physical } \\
\text { Education, Vol } \\
\text { 39, Issue 1, pp. } \\
\text { 121-125 - } 2020 \\
\text { Search engine: } \\
\text { EBSCO (UrblS - } \\
\text { Urbino Integrated } \\
\text { Search) }\end{array}$ \\
\hline
\end{tabular}

Source: own processing

\section{DOING SchOOL TODAY}

"What we say principle is often the end, and ending is to begin. The end that's where we start from" (Eliot, 1995, p.159)

In the beginning there is the objective to be set and then developed to find answers to crucial questions: What school today? Which methodologies between tradition and innovation to privilege? Which teaching styles to better reach the learning styles of the students?
Answers to be sought in a re-engagement, reassessment, re-formulation, re-formulation, reorganisation of our schooling, adapting to the new which is suddenly and quickly already old; where tradition must be mixed with the new which is advancing but which needs a basis on which to make sense.

As P. Offredi (2021) says, schools should be radically rethought, reforming programs and teaching methods. It would be useful to break down the wall between scientific and humanistic subjects, even today we carry the legacy of fascism with us. They are two cultures separated only at the behest of one of the two parties. We must not forget about students and contents, as in our schools anachronistic things are taught in an anachronistic way (Offredi, 2021). 
"A perspective centered on the liberation of the child, which can be accomplished only starting from the emancipation of his intelligence, and on the formation of the citizens of the future" (Baldacci, 2015, p. 17). A training that takes into account a re-conversion of objectives, content, means and tools, observations, checks and evaluations, shared, managed by several minds, several eyes, several hands of teachers who together give consistency to that unitary knowledge that goes beyond the disciplinary. A school, a university that dresses the knowledge of what has been, what is and what will be, in perfect synergy for a preparation that once worn by the student is at his measure, of authentic knowledge "It is in essence what changes the way we give meaning and sense to our world and to ourselves" (Floridi, 2019, p. 136). Teaching styles to be sought in knowledge, skills, competences and disturbing and summarizing Vittorino da Feltre: a good teacher, before sitting in the chair, must be an example. Prepared to give an educational and didactic teaching, "An effective education of the functions, integrated by skills in the reception and accompaniment, which corresponds to the operational and affective character of the movement, whose expressiveness becomes a communication witness of what the body feels and participates" (Pesci, 2009 , p. 157). Getting out of your comfort zone discipline is not always easy, but it is necessary to try, to try without being adventurous but forming the best with the help of updates and that permanent training that should never, ever be set aside. The stress that may result, can destabilize, making us experience negative moods that must be channeled, however, contained in its resistance, "a hard and resilient person can be likened to a very strong rubber band, able to withstand a strong traction and then return to the starting situation. Everything depends on the quality of the elastic" (Meazzini, 2019, pp. 14-15).

A teacher in distress but also a learner in technological hyper-immersion, "our sense is that $Z$ Generation will feel increasingly deprived, excluded, distressed or poor, to the point of incurring paralysis or psychological trauma, whenever they find themselves disconnected from the info sphere, like a fish out of water. One day, being an inforg will be so natural that any interruption in our normal flow of information will make us feel bad" (Floridi, 2017, p. 111).

\section{Open Methodologies (OM)}

We like to use, coining, in form and in substance, the term Open Methodologies, in our pluralistic vision of teaching, a mainstream that incorporates technological innovations because if we do not produce all-round knowledge, even learning is impoverished. An impoverishment that affects the Popperian scientific method, problem-hypothesis-test. Searching for a symbiosis between theory and practice, a union between all languages, verbal and not (body language, music, art), to give teaching more facets, more vision, more openings, new perspectives: transforming it into learning to read, interpret, decipher, move, in complexity. Concentrating and not fragmenting knowledge by going beyond what is seen. So we just have to include all the methodologies that will serve the purpose, none excluded, BUT that must meet, reach everyone respecting: intelligence, rhythms and learning styles, attention capacity, autonomy, working memory, personality styles, social roles, expectations. The technological language that is increasingly making its way among the various forms of knowledge, integrating them with an intelligent attention on the part of the teacher, at every level of school, in channelling it, guiding it in a literacy first and then in the awareness that will have to follow shared rules as well as the management of the Web. "The Web is a synthesis of Wordl wide web $=$ the plot or rather the web that holds together the vast world. [...] how much the web in a specifically informatic sense and in the widest sense interferes today and perhaps tomorrow even more on training models of all kinds, including pedagogical ones" (Santoni Rugiu, 2010, p.97). For choice, here we will not make a list of methodologies because they are intended in the plural, many, different and each one aimed at specific educational and didactic contents, stressing that it will be the teacher's skills, his ability to be within the context, to determine the best option, more appropriate to the individual and his specificity; a teacher who knows how to enhance everything: students, knowledge and skills. It is emphasized that knowledge in motion, linked to motor sciences, with a natural interdisciplinary vocation, will be the thread, the glue that will bind better and well the various languages; an advantageous conjunction to arrive well and sooner even at complex concepts.

\section{Conclusions}

Which school and which way of teaching of the future? Without disturbing extrasensory capacities, recalling thaumaturgic powers or answers with special effects a la Spielberg, we simply, humbly, try to propose that perhaps there is not a single answer but several, plural ones that increasingly must take into account words such as elasticity, flexibility, sharing, union, complicity, responsibility, re-elaboration, communion, cooperation. Words that are thick, that are worth a lot and to be understood in a global sense, for everything, in everything, "when a single person internalizes the values of civil cooperation, this becomes a common good, acting in favour of all those who can start cooperating even without an intrinsic or ethical reward for their action. A good result, and above all good news" (Bruni, 2018, p. 182). It is and will be a matter of choices: from the top to the base, may this base be 
solid, well implanted, strong with all that is needed and will be needed for future generations and beyond. "I wish you were a heretic because heresy from the Greek means choice. Heretic is the person who chooses. The heretic is the one who loves the search for truth more than truth. The heresy of deeds before that of words. The heresy that lies in ethics rather than in speeches. The heresy of coherence, of courage, of gratuitousness, of responsibility, of commitment. Today it is a heretic who puts his own freedom at the service of others, who commits his own freedom for those who are not free yet. A heretic is someone who is not satisfied with second-hand knowledge, someone who studies, who deepens, who gets involved in what he does, who believes that only in the "we" can the "l" can find fulfilment" (Don Ciotti, 2014). There is nothing more to add: perfect synthesis.

\section{References Références Referencias}

1. Baldacci, M., Frabboni, F., Zabalza, M. (2015). Maria Montessori e la scuola d'infanzia a nuovo indirizzo. Bergamo: Zeroseiup.

2. Bruni, L. (2018). La pubblica felicità. Milan: Vita e Pensiero.

3. Cecchini, J.A., \& Carriedo, A. (2020). Effects of an Interdisciplinary Approach Integrating Mathematics and Physical Education on Mathematical Learning and Physical Activity Levels. Journal of Teaching in Physical Education, 39, (1), pp. 121-125.

4. Coral-Mateu, J., \& Lleixà Arribas, T. (2016). Physical Education in content and integrated language learning: successful interaction between Physical Education and English as a foreign language. International Journal of Bilingual Education and Bilingualism, 19, (1), pp. 108-126.

5. Cottini, L. (2019). Vincere le sfide con la sindrome di down. Rome: Anicia.

6. Don Ciotti, L. (2014). Be Heretics. Speech at the National Congress of Italy Slow Food: Riva del Garda.

7. Eliot, T.S. (1995). The Wasteland - Four Quartets. Milan: Feltrinelli.

8. Encyclopedia Treccani online, (2021). Sustainability.

9. Filippou, F. (2015). The effect of an interdisciplinary Greek traditional dance, history, and anthropology program on male and female students' achievement goal orientations. Journal of Physical Education and Sport (JPES), 15, (3), Art 92, pp. 610-614.

10. Floridi, L. (2017). La quarta rivoluzione. Milan: Raffaello Cortina.

11. Floridi, L. (2019). Pensare l'infosfera. Milan: Raffaello Cortina.

12. Galimberti, U. (2002). II corpo. Milan: Feltrinelli.

13. Hastie, P.A. (2013). The Biome Project: developing a legitimate parallel curriculum for Physical Education and Life Sciences. Journal of Education
3-13; International Journal of Primary, Elementary and Early Years Education, 41, (5), pp. 462-476.

14. Meazzini, P. (2019). L'insegnante sotto stress. Rome: Anicia.

15. Nicolosi, S., Greco, C., \& Di Stefano, S. (2017). Integrating Physical Educationinto the Primary School Curriculum. A collaborative approach to interdisciplinary teaching. Training \& Teaching, XV, (2), Lecce: Pensa MultiMedia.

16. ONU, (2015). The 2030 Agenda for Sustainable Development.

17. Pesci, G. (2009). La psicomotricità funzionale. Scienza e metodologia. Rome: Armando.

18. Rosini, F. (2018). L'arte di ricominciare. Milan: San Paolo.

19. Santoni Rugiu, A. (2010). Piccolo dizionario per la storia sociale dell'educazione. Pisa: ETS.

20. Seeds, A., Pollom, G., \& Burton, B. (2015). Physical Education meets Physical Science: An interdisciplinary lesson allows students to experience Physical Science firsthand. National Science Teachers Association, Science and Children, 52, (6), pp. 39-44.

21. Thorburn, M., \& Collins D. (2003). Integrated Curriculum Models and their Effects on Teachers' Pedagogy Practices. European Physical Education Review, 9, (2), pp. 185-209.

\section{Online references}

1. Offredi, P. (2021) https://www.huffingtonpost.it/ entry/piergiorgio-odifreddi-a-scuola-abbattiamoilmuro-fra-materie-scientifiche-e-umanistiche_it_608 90f4ae4b0c15313ede2ec?utm_hp_ref=it-home page\&utm_source $=$ Facebook ${ }_{\text {ref }} \bar{f}=$ fbph\&utm_med ium =Social\&ncid =fcbklnkithpmg00000001\&utm_ campaign =it_main 